\title{
Molecular epidemiology of Hepatitis C Virus (HCV) in liver disease patients in Sri Lanka
}

\author{
D.B. Senevirathna ${ }^{1}$, Y. Wahalathanthri', P. Thiyagarajah ${ }^{2}$, A. Shani ${ }^{2}$, S. Jayasinghe ${ }^{3}$, N.D. Fernandopulle ${ }^{1}$ \\ ${ }^{1}$ Genetech Molecular Diagnostics and School of Gene Technology, Colombo, Sri Lanka, ${ }^{2}$ Lanka Hospital, Colombo, Sri Lanka, \\ ${ }^{3}$ Faculty of Medicine, University of Colombo, Sri Lanka
}

Background: Globally, hepatitis $\mathrm{C}$ virus (HCV) is an important cause of chronic liver disease. Genotypes of HCV are associated with different profiles of pathogenicity, infectivity, and antiviral therapy. The prevalence of HCV and distribution of HCV genotypes in Sri Lanka in comparison with the rest of Asia is not well known. Objective: The objective of the study was to investigate the presence of HCV and to genotype HCV in a group of Sri Lankan patients suspected to have liver disease. Methods: A total of 1933 samples were screened for HCV antibodies using ELISA and HCV RNA with RT-PCR methods. RNA positive samples were genotyped by type specific amplification and by DNA sequencing. Results: Out of the 1933 liver disease patients tested 219 (11.33\%) were detected to be positive for anti-HCV antibodies, out of which, $54(24.66 \%)$ were positive for HCV RNA. Furthermore out of 49 positively tested patients, 24 (48.97\%) were found to be categorised as HCV genotype 1. Conclusion: This result confirms previous observations that the contribution of HCV as a causative virus in liver disease patients is low in Sri Lanka. HCV genotype 1 was found to be the most predominant genotype in studied cohort of Sri Lankan liver disease patients.

Access this article online Website:

http://nepjol.info/index.php/AJMS DOI: 10.3126/ajms.v6i3.10741

Key words: Sri Lanka, Liver diseases, Hepacivirus, Genotype

\section{INTRODUCTION}

Hepatitis C virus (HCV), first identified in 1989, causes a slowly progressive disease affecting about 170 million (3\%) people worldwide. ${ }^{1,2}$ More than three million new cases of infection are reported annually, and epidemiological studies indicate a wide variation in its prevalence patterns in different continents and countries. ${ }^{2}$ The highest rate of HCV infection in the general population (10-20\%) has been reported in Egypt. ${ }^{3}$ It can vary from 5.3\% in parts of Africa to around $2.2 \%$ in Southeast Asia, $1.7 \%$ in North America, and $1 \%$ in Europe. There is wide variation within the Asia-Pacific region too: Western Pacific (3.9\%), Thailand $(1.5 \%)$, China (1.3\%), Japan (1.1\%), Taiwan $(1.0 \%)$ and Korea $(0.6 \%)$. Emerging data from the rest of Asia too suggests a wide variation in prevalence rates. In India the sero-prevalence rate was $1.85 \%$ of blood donors. Among the general population it has been studied that $4.57 \%$ in Pakistan, 1.8\% in Saudi Arabia and 2.1\% in Yemen have been recorded as being infected with the disease. ${ }^{4}$ Sri Lanka lacks data on the prevalence of $\mathrm{HCV}$ in the general population, but there have been a few studies reporting the seroprevalance of $\mathrm{HCV}$ antibodies among the patients with alcoholic cirrhosis, ${ }^{5}$ patients who have had multiple transfusions, ${ }^{6}$ and patients with chronic kidney diseases. ${ }^{7}$

The genome of HCV is a single-stranded, positive sense RNA molecule of approximately $9.6 \mathrm{~kb}$ in length. ${ }^{1}$ There is a remarkable genetic heterogeneity and divergence among HCV sequences which has lead to the categorization of HCV into "genotypes". HCV genotypes are related to regional distribution, ${ }^{8}$ clinical manifestation, response to treatment and prognosis of HCV infection. ${ }^{9}$ Genotypes 1-3 have a worldwide distribution. Types $1 \mathrm{a}$ and $1 \mathrm{~b}$ are the most common, accounting for about $60 \%$ of global infections. They predominate in Northern Europe and North America, and in Southern and Eastern Europe and Japan, respectively. Type 2 is less frequently represented 
than type 1. Type 3 is endemic in south-east Asia and is variably distributed in different countries. Genotype 4 is principally found in the Middle East, Egypt, and central Africa. Type 5 is almost exclusively found in South Africa, and genotypes 6-11 are distributed in Asia. ${ }^{2}$ In Sri Lanka, studies which were completed with low number of cases showed that genotype 1 and 3 are prevalent in liver disease patients and blood donors respectively. ${ }^{10,11}$

The objective of the study was to investigate the presence of HCV and to genotype HCV in a cohort of Sri Lankan patients suspected to have liver disease.

\section{MATERIALS AND METHODS}

A total of 1933 blood samples from patients who has various types of liver diseases were taken for this study. The samples were collected from the Apollo Hospital (now Lanka Hospitals), Colombo, Sri Lanka during the period of July 2006 to August 2010. There were no specific sampling methods and all the patients who were suspected to have liver diseases (patients with abnormal liver enzymes, fatty liver, acute hepatitis, chronic hepatitis, cirrhosis and hepatocellular carcinoma) were taken for this study. Ethical clearance was obtained from the University of Peradeniya, Sri Lanka.

Serum samples were tested by using an Enzyme Immuno Assay (EIA) for immunoglobulin $\mathrm{G}$ antibody to hepatitis $\mathrm{C}$ (VITROS ECi assay, Ortho-clinical diagnostics, Raritan, NJ) according to the manufacturer's instructions. The samples which showed a wide range of antibody titre ranging from 'marginally positive' to 'strongly positive' were taken as seropositives for this study. Repeat reactivity for HCV antibodies was not tested and all the antibody positive samples were tested for HCV RNA. Guanidium thiocyanate/ Silica RNA extraction was done as previously described by Boom et al $l^{12}$ and HCV RNA was detected by Reverse Transcription-Polymerase Chain Reaction (RT-PCR) using primers derived from the highly conserved 5 'untranslated (5'-UTR) genomic region as previously described. ${ }^{13}$

Nested RT-PCR was performed with type specific primers on HCV RNA positive specimens to determine the genotype status of $\mathrm{HCV}$ as previously described by Huang et $\mathrm{a}^{14,15}$ to detect type $1 \mathrm{~b}, 2 \mathrm{a}, 2 \mathrm{~b}$, and $1 \mathrm{a}, 3 \mathrm{a}$ respectively. However, some of the type $1 \mathrm{~b}$ PCR products were the result of cross-annealing of type $1 \mathrm{~b}$ primers with a cDNA template for type 1a. Therefore restriction enzyme digestion with restriction enzyme AccI was performed to confirm sub-type $1 \mathrm{~b} .{ }^{16}$

A total of $20 \mathrm{HCV}$ RNA positive specimens (representing different types and considering availability of the specimens) were further characterized by sequencing parts of the Core/E1 and NS5B regions of the HCV genome. Briefly, purified RNA was used to generate cDNA by reverse transcription. Nested RT-PCR was performed with sets of published primers to amplify DNA from Core/E1 or NS5B regions. ${ }^{3}$ The amplified products were separated in an agarose gel and purified with the Promega Wizard ${ }^{\circledR}$ PCR preps DNA purification system (Promega, Madison, WI, USA). DNA sequencing was performed at Eton Bio-Science, USA. The sequences were aligned in the BioEdit sequence alignment editor version $7.0 .9 .0^{17}$ by using ClustalW Multiple alignment. ${ }^{18}$ Phylogenetic tree for $\mathrm{HCV}$ which was based on Core/E1 sequence and genetic distances were calculated with MEGA software version 4 using the Maximum Likelihood model. ${ }^{19}$ The sequences of Core/E1 and NS5B of HCV strains in Sri Lanka were deposited in NCBI GenBank under the accession numbers given in Table 1.

\section{RESULTS}

Of 1933 liver disease patients only 219 (11.33\%) were positive for anti-HCV antibodies and of that, 54 (24.66\%) were positive for HCV RNA by RT-PCR. If we assume antibody negative samples are true negatives, of 1933 samples only 54 (2.79\%) were positive for HCV RNA.

Out of 54 HCV RNA positive samples, 48 samples were genotyped by combining two methods: Type specific PCR assay and DNA sequencing. The majority of the samples belonged to type $1 \mathrm{~b}(13,27.08 \%)$, followed by type $1 \mathrm{a}$ $(11,22.91 \%)$, type $3 \mathrm{a}(8,16.66 \%)$, type $2 \mathrm{a}(6,12.50 \%)$, type $2 \mathrm{~b}(6,12.50 \%)$, type $4 \mathrm{a}(2,4.17 \%)$, type $3 \mathrm{~b}(1,2.08 \%)$, and mixed infection of genotypes $1 \mathrm{~b}$ and $2 \mathrm{~b}(1,2.08 \%)$. Therefore, it was found that genotype 1 is the most predominant (24 cases out of 48, 50\%) genotype among the studied cohort of liver disease patients.

\section{DISCUSSION}

Here, we present the occurrence of HCV in a cohort of liver disease patients in Sri Lanka and their genetic diversity. In Egypt, the country that has recorded the highest prevalence of $\mathrm{HCV}$, it was found $73.5 \%$ had antibodies to hepatitis $\mathrm{C}$ among the liver disease patients. ${ }^{20}$ In India the country which is more close to Sri Lanka, it was found that the prevalence of anti-HCV antibodies ranged from $10.8 \%$ to as high as $48.5 \%$ throughout the country. Furthermore in a study done in Delhi, HCV RNA was detected in $15.5 \%$ of patients with chronic liver disease. ${ }^{21}$ Therefore our data suggests that the occurrence of HCV among the liver disease patients is relatively low in Sri Lanka. 


\begin{tabular}{|c|c|c|c|c|c|}
\hline \multirow[t]{2}{*}{ Isolate } & \multirow{2}{*}{$\begin{array}{l}\text { Genotypes with } \\
\text { Type-Specific PCR }\end{array}$} & \multicolumn{4}{|c|}{ Genotypes with DNA sequencing } \\
\hline & & Core/E & Accession no. & NS5B & Accession no. \\
\hline $\mathrm{HCV} 1$ & $1 \mathrm{a}$ & $1 \mathrm{a}$ & GU075876 & NA & - \\
\hline HCV 2 & $1 \mathrm{a}$ & $1 \mathrm{a}$ & EU849146 & NA & - \\
\hline HCV 3 & $1 \mathrm{a}$ & $1 \mathrm{a}$ & EU849147 & $1 a$ & EU867440 \\
\hline HCV 4 & $1 \mathrm{a}$ & $1 \mathrm{a}$ & EU849148 & NA & - \\
\hline HCV 5 & $1 \mathrm{a}$ & $1 \mathrm{a}$ & EU849149 & $1 a$ & EU867441 \\
\hline HCV 6 & $1 \mathrm{a}$ & $1 \mathrm{a}$ & EU849150 & NA & - \\
\hline $\mathrm{HCV} 7$ & $1 \mathrm{a}$ & $1 \mathrm{a}$ & EU849151 & NA & - \\
\hline HCV 8 & $1 \mathrm{a}$ & $1 \mathrm{a}$ & EU849139 & NA & - \\
\hline HCV 9 & $1 b$ & $1 b$ & EU849140 & NA & - \\
\hline HCV 10 & $1 b$ & $1 b$ & EU849141 & NA & - \\
\hline HCV 11 & $2 a$ & $2 a$ & EU849142 & NA & - \\
\hline HCV 12 & $2 a$ & $2 a$ & EU849143 & NA & - \\
\hline HCV 13 & $2 a$ & $2 a$ & EU849144 & $2 a$ & EU867439 \\
\hline HCV 14 & UT & $4 a$ & GU075875 & NA & - \\
\hline HCV 15 & $2 b$ & NA & - & $2 b$ & EU867438 \\
\hline HCV 16 & $3 a$ & $3 a$ & GU075872 & $3 a$ & GU075878 \\
\hline HCV 17 & $3 a$ & $3 a$ & GU075873 & $3 a$ & GU075877 \\
\hline HCV 18 & $1 b \& 2 b$ & NA & - & $2 b$ & EU867437 \\
\hline HCV 19 & UT & $3 b$ & FJ236904 & NA & - \\
\hline HCV 20 & UT & $4 a$ & GU075874 & NA & - \\
\hline
\end{tabular}

Where NA: Not Amplified, UT: Un Typed

We detected $219 \mathrm{HCV}$ antibody positive specimens but only $54(24.66 \%)$ of these were confirmed by RT-PCR. These results may indicate that false-positive ELISA results for HCV are frequent. False-positive results could be due to nonspecific antibody binding or to cross-reactivity with other circulating organisms. ${ }^{22}$ Alternatively; perhaps true antibody positive participants did not have positive RT-PCR results because they had cleared HCV viremia. ${ }^{22}$

Out of 20 specimens which were further characterised by sequencing, 18 and 7 were amplified and sequenced with Core/E1 and NS5B primers respectively. Based on their relative positions on the phylogenetic tree (Figure 1), and their relative distance from known reference types, it was possible to assign subtypes to the specimens in this study. Therefore, genotyping results of the two typing methods could be compared (Table 1) and concordant results were obtained for all the tested samples except the sample which gave mix infection of type $1 \mathrm{~b}$ and $2 \mathrm{~b}$ with type specific primers. Sequence analysis of the NS5B region was able to detect it as type $2 \mathrm{~b}$ and Core/E1 region failed to amplify. Theoretically, in true mixed infections, one of the genotypes might be represented in an extremely large proportion with respect to the others. ${ }^{23}$ However, type specific PCR was found to be most sensitive method to detect mix infection of $\mathrm{HCV}^{23}$

The profile of liver disease was obtained for the HCV RNA positive patients and it is compared with the genotype of respective isolates (Figure 2). It was found that there was no clear relationship between the profile of the disease and the genotype. However, due to the low numbers of samples in each category, a statistical analysis could not be performed to find out the statistical significance of this observation.

A separate phylogenetic analysis was performed with specimens which belonged to genotype 1 . In the Core/E1 phylogeny of genotype 1, there was a one sequence (EU849140) which grouped with global subtype $1 \mathrm{~b}$ references with a higher bootstrap values over 1000 replicates. However, there was another Sri Lankan isolate (EU849141) which fell outside the sub-type 1b cluster with a low bootstrap support. The low bootstrap value can be due to limited phylogenetic information in relation to the particular sequence. ${ }^{24}$ The highest similarity scores for the isolate EU849141 was 77\% with an isolate (QC 156/ EF115770) found from Canada, classified as sub-type 1h. The second highest similarity was observed with an isolate (I91/FJ207711) from USA which belonged to sub-type 1b. Because of these observations and very low homology with already available sequences, it could be assumed that it may belong to a previously unrecognized sub-type. However, according to the criteria proposed by Simmonds et a ${ }^{25}$ to assign a new-sub-type there should be at least 3 strains with the new sequence and also at least two regions within the coding sequence should be sequenced. Because it was not possible to find more isolates in this study with this new variant and also because the NS5B region could not be sequenced for the particular isolate, a new sub-type assignment was not attempted. However, this could be a new subtype of HCV genotype 1. 


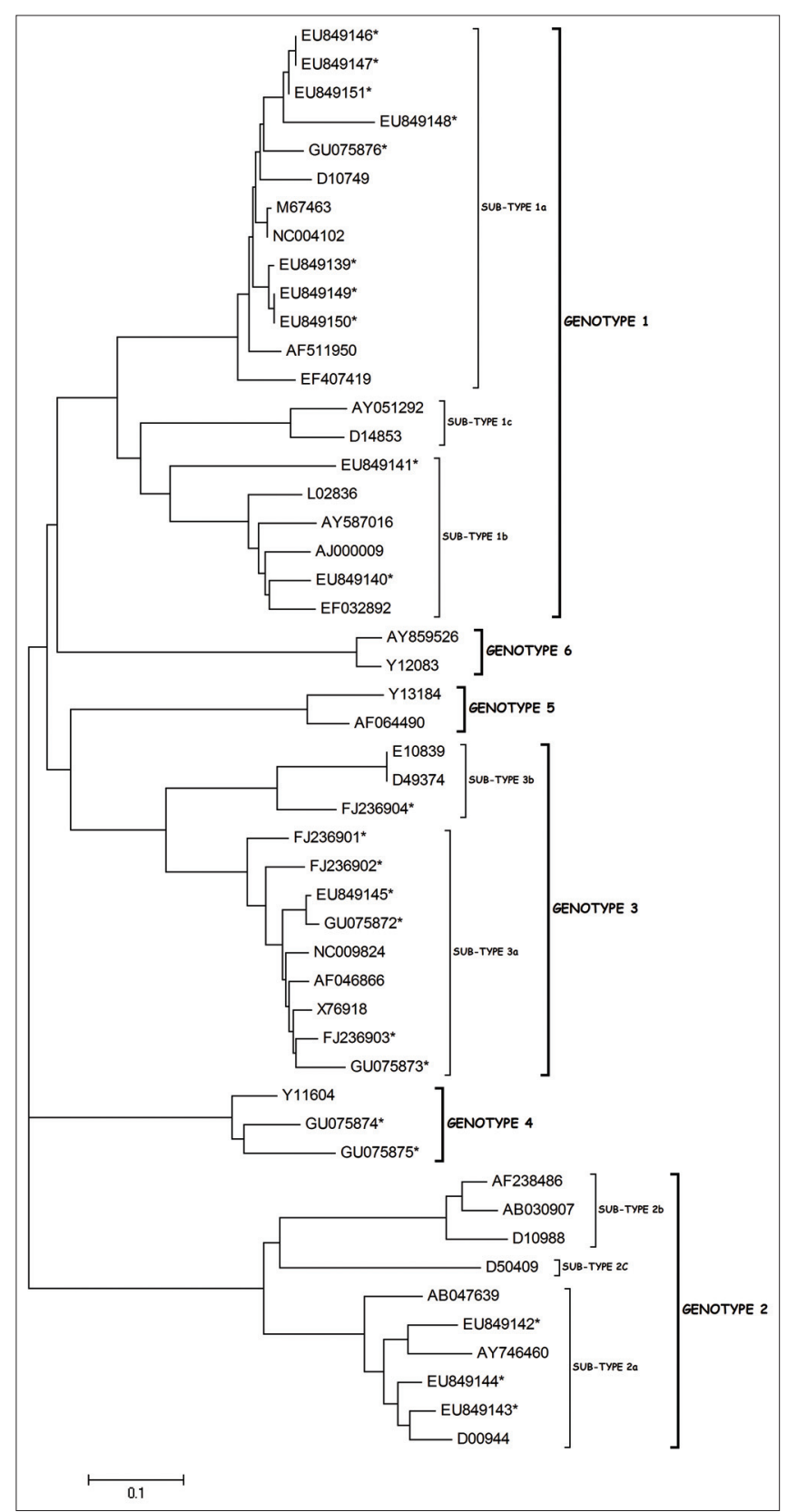

Figure 1: Phylogenetic tree based on Core/E1 region of $22 \mathrm{HCV}$ isolates in Sri Lanka and reference sequences of genotype 1 to 6 . Specimens from this study are labeled with the accession numbers plus "*” and reference sequences used are labeled with their accession numbers. The bar indicates genetic distance scale expressed as substitutions per 100 bases

Genetic distances between isolates of a virus could give an indication of the epidemiology of that infection. Low genetic distance between isolates is indicatives of recent spreading of the virus from local sources, whereas greater genetic distances indicates either regionalized spreading within a country or the introduction of isolates from external sources. ${ }^{26}$ The mean genetic distance measurements among the Sri Lankan genotype 1 Core/E1 region was comparatively low (0.085) and this low genetic distance being indicative of

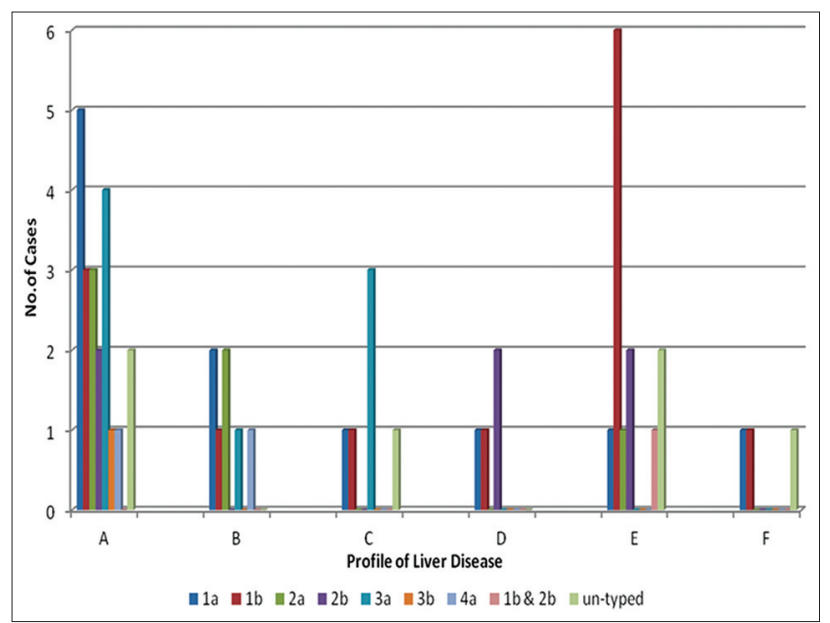

Figure 2: A genotype distribution of $\mathrm{HCV}$ with respect to each category of liver profile. (A - Patients who shows abnormal liver enzymes, B - Fatty liver, C - Abnormal liver enzyme + Fatty liver, D - Hepatitis, E - Cirrhosis, F - Hepatocellular carcinoma)

internal transmission of the virus. It shows that although Sri Lanka has the low number of intravenous drug users as well as efficient blood screening system before transfusion, still there may be some gaps to be filled.

\section{CONCLUSION}

The result confirms previous observations that the contribution of $\mathrm{HCV}$ as a causative virus in liver disease patients is low in Sri Lanka. HCV genotype 1 was found to be the most predominant genotype in studied cohort of Sri Lankan liver disease patients.

\section{ACKNOWLEDGEMENT}

We like to thank Mr. D N Gunasekera and the staff of Genetech Molecular Diagnostics and Dr. Surjith Somaiyha (Counsultant Urologist, Lanka Hospital, Colombo). We specially thank Prof. Aravinda De Silva and Ms. Anne Broadwater from the University of North Carolina, USA, for critical review and DNA sequencing respectively.

\section{REFERENCE}

1. Choo Q, Kuo G, Weiner A, Overby L, Bradley D and Houghton $M$. Isolation of a cDNA clone derived from a blood borne non-A, non-B viral hepatitis genome. Science 1989; 244(4902):359-62.

2. Robert S, Brown J, and Gaglio J. Scope of Worldwide Hepatitis $C$ Problem. Liver Transplantation 2003; 9(11):S10-S13.

3. Stuart C, Ray R, Anthony C, Jens B and David L. Genetic Epidemiology of Hepatitis C Virus throughout Egypt. Journal of Infectious Disease 2000; 182:698-707.

4. Theodore $S$ and Mazen M. Epidemiology of Hepatitis $C$ virus (HCV) infection. International Journal of Medical Sciences, 2006; 3(2):41-46. 
5. Silva $H$, Vitarana $T$, Ranatunga $N$, Breschkin A, Withane $N$ and Kularatne W. Prevalence of hepatitis C virus markers in Sri Lankan patients with alcoholic cirrhosis. Journal of Gastroenterology and Hepatology 1994; 9(4):381-384.

6. Fernando S, Fernando SDD, Sheriff MHR and Vitarana UT. Antibodies to Hepatitis $\mathrm{C}$ virus in patients who have had multiple transfusions in Sri Lanka. Ceylon Medical Journal 2001; 46(3):91-94.

7. Wai S, Lanerolle R, Beeching N, Mananwatte S, Nazar A, Sheriff $M$, et al. Low prevalence of hepatitis $C$ in patients with chronic kidney disease in Sri Lanka. Hepatology International 2011; 5(1):04-25.

8. Liselotte V, Verhaest I, Lamzira S, Hernandez A, Zangerle R, Boufassa $F$, et al. Spread of Hepatitis $C$ virus among European injection drug users infected with HIV: A phylogenetic analysis. The Journal of Infectious Disease 2004; 189:292-302.

9. Martinot M, Roudot F, Mendel I, Coste J, Izopet J, Duverlie G, and Marcellin P. Hepatitis C virus genotypes in France: relationship with epidemiology, pathogenicity and response to interferon therapy. Journal of Viral Hepatitis 1999; 6: 435-443.

10. Senevirathna $D$, Amaduwagae $S$, Weerasingha $S$, Jayasinghe $S$, Fenandupulle N. HCV in healthy blood donors in Sri Lanka. Asian Journal of Transfusion Science 2011; 5: 23-25.

11. Senevirathna D, Ranaweera D, Abeysekera D, Kanakarathana N, Silva D, Abeysundara S, et al. Genotypes of HCV in liver disease patients in Sri Lanka. Southeast Asian Journal of Tropical Medicine and Public Health 2008; 39:1054-1056.

12. Boom R, Sol $C$, Salimans $M$, Jansen $L$, Wertheim $P$ and Noordaa J. Rapid and Simple Method for Purification of Nucleic Acids. Journal of Clinical Microbiology 1990; 28(3):495-503.

13. Cha $T$, Beall $E$ and Irvine B. At least five related, but distinct, hepatitis $\mathrm{C}$ viral genotypes exist. Proceedings of the National Academy of Sciences of the United States of America 1992; 89:7144-7148.

14. Huang F, Zhao GZ and Li Y. HCV genotypes in Hepatitis C patients and their clinical significance. World journal of gastroenterology 1999; 5(6): 547-549.

15. Ohno T, Mizokami M, Wu R, Saleh M, Ohba K, Orito E, et al. New hepatitis $C$ virus genotyping system that allows for identification of HCV genotypes 1a, 1b, 2a, 2b, 3a, 3b, 4, 5a and 6a. Journal of Clinical Microbiology 1997; 35: 201-207.

16. Andonov A and Chaudhary R. Genotyping of Canadian hepatitis $C$ virus isolates by PCR. Journal of Clinical Microbiology 1994; 32(8):2031-2034.

17. Hall T. BioEdit: A user-friendly biological sequence alignment editor and analysis program for Windows 95/98/NT. Nucleic acids symposium series 1999; 41: 95-98.

18. Thompson JD, Higgins DG and Gibson TJ. CLUSTAL W: Improving the sensitivity of progressive multiple sequence alignment through sequence weighting, position-specific gap penalties and weight matrix choice. Nucleic Acids Research 1994; 22:4673-4680.

19. Tamura K, Dudley J, Nei M and Kumar S. MEGA4: Molecular Evolutionary Genetics Analysis (MEGA) software version 4.0. Molecular Biology and Evaluation 2007; 24:1596-1599.

20. Waked I, Saleh S, Moustafa M, Raouf A, Thomas D and Strickland G. High prevalence of hepatitis $C$ in Egyptian patients with chronic liver disease. Gut 1995; 37:105-107.

21. Mukhopadhya A. Hepatitis $C$ in India. Journal of Biosciences 2008; 33(4): 465-473.

22. Biggar R, Ortiz-Conde B, Bagni R, Bakaki P, Wang C and Engels $E$. Hepatitis $C$ virus genotype 4 in Ugandan children and their mothers. Emerging Infectious Disease 2006; 12(9):1440-1443.

23. Forns X, Maluenda D, Labrador F, Ampurdanes S, Olmedo E, Costa J, et al. Comparative study of three methods for Genotyping Hepatitis C virus strains in samples from Spanish patients. Journal of Clinical Microbiology 1996; 34(10):2516-2521.

24. Ndjomou J, Oliver G and Matz B. Phylogenetic analysis of hepatitis $C$ virus isolates indicates a unique pattern of endemic infection in Cameroon. Journal of General Virology 2003; 84:2333-2341.

25. Simmonds P, Bukh J, Combet C, Gilbert Deleage, Enomoto N, Feinstone $\mathrm{S}$, et al. Consensus Proposals for a unified system of Nomenclature of Hepatitis C virus genotypes. Hepatology 2005; 42: 962-973.

26. Ryan C, Elliott J, Middleton T, Mijch A, Street C, Hellard M, et al. The Molecular Epidemiology of HIV Type 1 among Vietnamese Australian Injecting Drug Users in Melbourne, Australia. Aids Research and Human Retroviruses 2004; 20(12):1364-1367. 